community action, the Global Fund to Fight AIDS, Tuberculosis, and Malaria provided $\$ 2.7 \mathrm{~m}$ for fighting malaria and tuberculosis through the basic development needs programme in seven districts for 2005-6. ${ }^{21}$

\section{Sustaining community based initiatives}

Commitment of national and local governments, collaboration with civil society, and some form of external financial support are essential to maintain and expand these community based initiatives. Monitoring, evaluation, and documentation need to be improved to inform their further development. But care should be taken that data collection and management does not compromise the participation of community members. A feeling of ownership is essential.

Contributors and sources: All authors discussed the concept and formulation of the paper and went through the revisions. SW wrote the first draft and provided literature from the region on social determinants, MA provided basic information on the work of community based initiatives in the region, SS provided the initial conceptualisation and developed the subsequent versions. MA has been working in the area of community based initiatives since 2000; SS is the regional focal person responsible for the social determinants of health; SW is a social scientist with several years of experience in the region.

Competing interests: None declared.

1 Irwin A, Valentine N, Brown C, Loewenson R, Solar O, Brown H, et al. The Commission on Social Determinants of Health: tackling the social roots of health inequities. PloS Medicine 2006;3(6):e106.

2 Feachem RGA. Poverty and inequity: a proper focus for the new century. Bull World Health Organ 2000;78:1-2.

3 Fikree FF, Pasha O. Role of gender in health disparity: the South Asian context. BMJ 2004;328:823-6.

Yount KM. Provider bias in the treatment of diarrhea among boys and girls attending public facilities in Minia, Egypt. Soc Sci Med 2003;56:753-68.

attending public facilities in Minia, Egypt. Soc Sci Med 2003;56:753-68.
WHO Regional Office for the Eastern Mediterranean. Social and health WHO Regional Office for the Eastern Mediterranean. Social and health
indicators for countries of the Eastern Mediterranean. Cairo: EMRO, 2006.
6 League of Arab States, Republic of Yemen Ministry of Health and Population, Central Statistical Organization Yemen. Yemen family health survey: principal report 2003. Sanaa: CSO, 2005.

7 Noorbala AA, Bagheri Yadzi SA, Yasamy MT, Mohammad K. Mental health survey of the adult population in Iran. $B r J$ Psychiatry 2004;184:70-3.

8 Maziak W, Asfar T, Mzayek F, Fouad FM, Kilzieh N. Sociodemographic correlates of psychiatric morbidity among low-income women in Aleppo, Syria, Soc Sci Med 2002:54:1419-27.

9 Mohammadi MR, Ghanizadeh A, Rahgozart M, Noorbala AA, Malekafzali H, Davidian H, et al. Suicidal attempt and psychiatric disorders in Iran. Suicide Life Threat Behav 2005;35:309-16.

10 El-Zanaty F, Hussein EM, Shawky GA, Way AA, Kishor S. Egypt demographic and health survey 1995. Calverton, MD: National Population Council, Macro International, 1996.

11 Jordanian Department of Statistics, ORC Macro. Jordan population and family health survey 2002. Calverton, MD: ORC Macro, 2003.

12 Morroco Ministry of Health. Morocco demographic and health surves. 2003-4. Calverton, MD: ORC Macro, 2004

13 Mumtaza Z, Salway S. “I never go anywhere”: extricating the links between women's mobility and uptake of reproductive health services in Pakistan, Soc Sci Med 2005;60:1751-65.

14 Unicef. Innocenti digest: changing harmful social convention: female genital mutilation/cutting. Florence: Unicef Innocenti Research Centre, 2005.

15 El-Gibaly O, Ibrahim B, Mensch BS, Clark WH. The decline of female circumcision in Egypt: evidence and interpretation, Soc Sci Med 2002;54:205-20.

16 Federal Ministry of Health, Sudan. Basic development needs programme: Dar Mali village, a successful story of sustainable community development. Khartoum: Primary Health Care Support Directorate, 2003.

17 World Health Organization. Evaluation of the basic development needs programme in Djibouti, February 2005. Cairo: Eastern Mediterranean Regional Office, 2005.

18 World Health Organization. Evaluation of the basic development need programme in the Republic of Yemen. Cairo: Eastern Mediterranean Regional Office, 2005 .

19 World Health Organization. Validation of the evaluation of community based initiatives in Islamic Republic of Iran. Cairo: Eastern Mediterranean Regional Office, 2006.

20 Department of Health, Government of Sindh. PC-I proforma of the strengthening of the basic development needs programme in Sindh, July 2005 June 2008. Karachi: $\mathrm{DoH}, 2006$.

June 2008. Karachi: DoH, 2006.
Global Fund to Fight AIDS, Tuberculosis, and Malaria. Application form for the proposal to Global Fund. CCM Pakistan proposal round three. Geneva, 2003. www.theglobalfund.org/search/docs/3PKSM_698_0_full.pdf (accessed 28 Sep 2006).

doi $10.1136 /$ bmj.38988.607836.68

\title{
Regional collaboration in the Middle East to deal with H5N1 avian flu
}

\author{
Alex Leventhal, Assad Ramlawi, Adel Belbiesi, Ran D Balicer
}

In 2005-6 Arab and Israeli collaboration contained outbreaks of avian flu in the Middle East. This initiative shows how building relationships through joint efforts creates an infrastructure for cross border collaboration during emergencies

Israel Ministry of Health, PO Box 1176 , Jerusalem 91010, Israel

Alex Leventhal director of public health services

Palestinian

Authority Ministry of Health, Ramallah, West Bank

Assad Ramlawi director general of primary care and public health

continued over
Recent emerging infectious diseases have changed the way that outbreaks are dealt with-from a mainly local approach to a regional and even global one. The importance of global collaboration orchestrated by the World Health Organization has been demonstrated during recent outbreaks of severe acute respiratory syndrome and avian flu. ${ }^{12}$

We describe an example of Arab and Israeli collaboration in the Middle East on a public health issue. Cooperation between Israeli, Jordanian, and Palestinian veterinary and public health services contained outbreaks of $\mathrm{H}_{5} \mathrm{~N} 1$ avian flu. The measures taken enabled these countries to avoid human infection, increased public confidence, and reduced potential adverse outcomes of the outbreaks. This success shows how building professional and personal relationships through joint efforts for tackling common infectious diseases creates an infrastructure for cross border collaboration during emergencies.

\section{Geopolitical circumstances in the Middle East}

Jordan, the Palestinian Authority, and Israel border one another. The distance between the three capital cities is less than $80 \mathrm{~km}$. Palestinians who live in all three countries have close family and commercial ties with each other. The citizens of these countries live as one "epidemiological family"."

See table on bmj.com 
Jordan, the Palestinian Authority, and Israel are located at the junction of three continents, between the Mediterranean and the Arabian Desert. They form a "bottleneck" (figure) through which large numbers of migratory birds pass during spring and autumn. An estimated 500 million birds pass through Israel annually, ${ }^{4}$ and provide a continuous source of viruses such as those responsible for West Nile fever and avian flu.

\section{Building trilateral cooperation}

The Jordan-Israel Peace Treaty was signed in October 1994. In the same year, after the signing of the Oslo Accord in September 1993, authority over health matters for the occupied territory was transferred from Israel to the Palestinian Authority's Ministry of Health. The Public Health Joint Committee, which was created by the accord and comprised Israeli and Palestinian Authority officials, met regularly to exchange public health data and discuss immunisation, epidemiological reports, and disease outbreaks. Other cooperative efforts on health matters have been described..$^{5-7}$ These meetings became scarce after the Palestinian uprising (Intifadah) in 2000, although ad hoc bilateral meetings about outbreak control took place at the request of either party.

In 2003, an international partnership of two non-governmental organisations (Search for Common Ground and the Nuclear Threat Initiative) began facilitating regional cooperation in public health. This established the Middle East Consortium on Infectious Disease Surveillance, in which the ministries of health for Israel, the Palestinian Authority, and Jordan share data on food borne disease outbreaks; the Egyptian Ministry of Health has also participated in this project. As part of the project, joint training courses were held on interventional epidemiology and on laboratory technologies, further promoting collaboration among the parties.

\section{Preparing for pandemic and avian influenza}

All three ministries of health began drafting a national plan for pandemic and avian flu in 2003 or before, and these efforts gained momentum in 2005. As the threat came closer with outbreaks in poultry in Turkey (October 2005) and Iraq (January 2006), and soon after in humans, ${ }^{8}$ a Middle East meeting on the issue was agreed. The Istanbul conference (14-16 December 2005) was organised by Search for Common Ground and attended by senior officials from the ministries of health and agriculture of Jordan, Israel, the Palestinian Authority, and Egypt as well as experts from WHO, US Centers for Disease Control, and the European Union. Each country presented its national plan and the foundation was laid for the timely exchange of information in the likely case of an outbreak of avian flu.

In February 2006 a meeting on avian flu took place on the Allenby-King Hussein Bridge-a land crossing between Israel and Jordan-to share information on recent developments in preparedness for avian flu.

On the next day, the first outbreak of avian flu in Egypt was detected-backyard poultry, wild birds, and humans were affected. ${ }^{9}$ Although this outbreak took place hundreds of miles from Jordan, Israel, and the Palestinian Authority, the threat became clearly imminent. The table summarises the timeline of outbreaks of avian flu in the three countries.

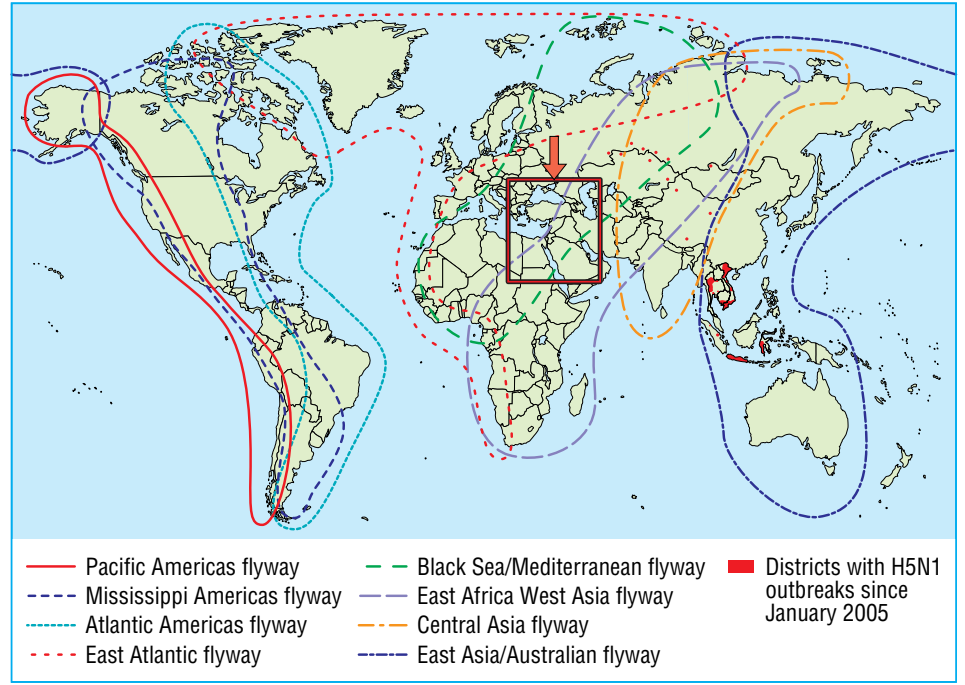

H5N1 avian flu outbreaks in 2005 and major pathways of migrating birds, highlighting the position of Jordan, the Palestinian Authority, and Israel at the junction of three continents. Adapted from a publication of the United Nations Food and Agriculture Organization, 2005

\section{Outbreaks of avian flu in Israel}

On 16 March 2006, the first case in Israel was diagnosed in industrially reared turkeys just across the border with the Gaza Strip. The Israeli central veterinary laboratory confirmed that the virus was strain H5N1. Four suspected human cases later turned out to be negative.

Contacts at the Palestinian and Jordanian ministries of health were immediately phoned, and the World Organisation for Animal Health (OIE) and WHO were notified. Overall, nine outbreaks were recorded in industrial poultry coops in Israel between 16 and 31 March. Five were in coops bordering the Gaza Strip, of which one was close to the Egyptian border. One outbreak was near Jerusalem, close to the West Bank, and one was in the northern Jordan valley near the border between Israel and Jordan. All birds within $3 \mathrm{~km}$ of the nine outbreak foci (1.2 million birds) were culled (using poison in drinking water).

\section{Outbreaks of avian flu in the Palestinian Authority}

Samples from sick poultry in Gaza sent by the Palestinian Authority veterinary services to the Israeli central veterinary laboratory on 22 March were positive for H5N1. On that day, Israeli and Palestinian veterinary and health officials took part in a meeting at the Gaza Crossing. Protocols for coping with the outbreak and transferring protective personal equipment, Tamiflu, and poison for culling poultry from Israel to the Palestinian Authority were set up. In the coming two weeks H5N1 virus was diagnosed in four foci along the Gaza Strip in industrial coops and backyard poultry. Around 600000 birds were culled.

\section{Outbreak of avian flu in Jordan}

On 24 March 2006, Jordan reported an H5N1 outbreak in backyard turkeys in a village east of the Jordan valley, $25 \mathrm{~km}$ northeast of the infected Israeli coop in the Jordan valley. This was promptly reported to Israeli and Palestinian contacts in the health and agriculture ministries. The Jordanian authorities culled 20000 birds in the $3 \mathrm{~km}$ protective zone.
Jordan Ministry of Health, Amman, Jordan

Adel Belbiesi director of disease control

Steering Committee for Pandemic Influenza

Influenza
Preparedness Ramat-Gan 52392, Israel

Ran D Balicer epidemiologist, preparedness plan coeditor

Correspondence to: A Leventhal leventhal_a@ yahoo.com 


\section{Summary points}

Coordinated cross country planning helped mitigate a potential public health crisis due to multiple outbreaks of avian flu in an area of conflict (Jordan, the Palestinian Authority, and Israel)

Building professional and personal relationships through joint efforts on preparedness creates an infrastructure for cross border collaboration during emergencies

Sharing and harmonising individual countries' preparedness plans for pandemic and avian flu helped synchronise efforts during the outbreaks

Cross country cooperation of veterinary and public health services helped contain outbreaks of avian flu in Israel, Jordan, and the Palestinian Authority

Extensive and uniform measures taken to tackle the outbreaks across the borders enabled the countries to avoid human infection, increase public confidence, and reduce adverse outcomes of the outbreaks

Three days later, a meeting between the three countries took place in Jerusalem, also attended by the WHO officer to the Palestinian Authority and a member of the Egyptian embassy in Israel. Information on the current situation in the region was shared, as were issues that needed cooperation, coordination, and assistance between the health and agriculture ministries.

\section{Successful outcome of collaboration}

Since 31 March 2006, no further outbreaks of avian flu have been detected in Jordan, Israel, or the Palestinian Authority, whereas outbreaks have continued in neighbouring Egypt. ${ }^{8}$

Although we do not know exactly how avian flu spread in these countries, all outbreaks were caused by the same $\mathrm{H} 5 \mathrm{~N} 1$ virus strain. It has been speculated that the disease was spread between flocks in Israel (industrial coops), Jordan (backyard poultry), and the Palestinian Authority (both industrial and backyard poultry) by unintentional mechanical or human driven means. In three of the outbreak foci, the $3 \mathrm{~km}$ protection zone (in which all birds were culled) crossed borders and included areas in Israel and the Palestinian Authority. These culling operations required close collaboration between veterinary and public health services within each country, and also between countries. Personal protective equipment was used and cullers and contacts treated prophylactically according to a protocol previously agreed on in regional meetings. These measures evidently paid off, as no transmission to humans was detected in the three countries.

In May 2005, the World Health Assembly adopted a set of International Health Regulations ${ }^{10}$ that set out ways of reporting to neighbouring countries and to WHO during outbreaks of infectious diseases. Although these regulations are not mandatory until June 2007 , they were implemented by the three countries during this outbreak and proved to be effective.
The Middle East Consortium on Infectious Disease Surveillance promoted regular reporting, strategic planning, and training meetings. Working and personal relationships should be built up over years of mutual cooperation rather than being instigated at times of emergency. Such relationships provide the infrastructure needed to enable collaboration in areas of conflict that pays off during emergencies, such as outbreaks of infectious disease.

We believe that the cooperation, mutual reporting, and assistance described here had an important effect during these outbreaks of avian flu. The opportunity to compare and synchronise preparedness plans before the event helped prevent the spread of the disease in these countries. The cooperation resulted in tangible help, such as training technicians locally and supplying equipment for culling birds. Public health officials were also updated by their counterparts in a timely manner to prevent contradicting messages from the media that could hinder public trust-despite borders, modern communication enables media messages in neighbouring countries to be compared quickly.

Such collaboration also helped build the confidence needed to manage pandemic flu or any health related crisis that crosses borders. The countries continued to collaborate on infectious diseases of common interest (ad hoc and at a low profile) even during the outbreak of violence in the Middle East during the summer of 2006.

Our article shows that irrespective of political circumstances, the common threat of an emerging infectious disease serves as an opportunity to bridge disputes and focus on humanitarian and health matters for the common good of all bordering countries.

Contributors and sources: All authors helped create and revise the manuscript; the final version was approved by all authors. The authors are top public health officials in Jordan, the Palestinian Authority, and Israel. They played a prominent part in designing preparedness plans for pandemic and avian flu in their respective countries. $\mathrm{AL}, \mathrm{AR}$, and $\mathrm{AB}$ coordinated cross country communication by reporting, sharing information, and attending coordination meetings during the outbreaks. AL is guarantor.

Competing interests: None declared.

Bell DM. Public health interventions and SARS spread, 2003. Emerg Infect Dis 2004;10:1900-6.

2 Ress P. WHO agrees global action plan to control avian flu. BMJ 2005;331:1164.

3 Tulchinsky T. One epidemiologic family changing disease patterns and the health status of the Palestinian population of the West Bank and Gaza. In: Barnea T, Husseini R, eds. Separate and cooperate, cooperate and separate. Portsmouth, NH, USA: Greenwood Publishing Group, 2002.

4 Israel Ornithological Center. Migrating birds know no boundaries. www birds.org.il/show_item.asp?itemId $=1700 \&$ levelId $=457$ (last accessed 25 Jun 2006).

5 Leventhal A, Melville L, Berry EM. Public health education in a conflict area: a report from Israel. Lancet 2003;361:1222.

6 Levin A. Middle East Cancer Consortium stays on track to collect data J Natl Cancer Inst 1998;90:807-8.

7 Skinner H, Abdeen Z, Abdeen H, Aber P, Al-Masri M, Attias J, et al. Promoting Arab and Israeli cooperation: peacebuilding through health initiatives. Lancet 2005;365:1274-7.

8 World Health Organization. H5N1 avian influenza:timeline. www.who.int/ entity/csr/disease/avian_influenza/timeline.pdf (last accessed 25 Jun 2006).

9 World Health Organization. Avian influenza-situation in Egypt, 20 March 2006. http://www.who.int/csr/don/2006_03_20/en/index.html (last accessed 25 Jun 2006).

10 World Health Organization. WHA58.3. Revision of the International Health Regulations, May 2005. www.who.int/gb/ebwha/pdf files/WHA58/ Regulations, May 2005. Www.who.int/gb/e
WHA58_3-en.pdf (last accessed 25 Jun 2006).

(Accepted 22 September 2006)

doi $10.1136 /$ bmj.38994.420926.80 